\title{
Physicochemical and Spectroscopic Elemental Analysis of Ground Water in Thickly Populated and Industrial Area of Quetta Valley Pakistan
}

\author{
Hayatullah Khan ${ }^{1}$, Attiq-ur-Rehman Kakar ${ }^{2 *}$, Samiullah Khan ${ }^{2}$, Naqeebullah Khan ${ }^{2}$, Irshad Ali ${ }^{2}$ \\ and Abdul Baqi Achakzai ${ }^{1}$ \\ ${ }^{1}$ Colleges, Higher and Technical Education Department, Balochistan, Quetta 87300-Pakistan. \\ ${ }^{2}$ Department of Chemistry, University of Balochistan, Quetta 87300-Pakistan. \\ * Corresponding author: arkakar10@gmail.com
}

\begin{abstract}
Quetta valley the capital of Balochistan Province, has faced twice the rush of immigrants i.e; Afghan refugees after Saur Revolution and people from interior Balochistan due to drought in Balochishan from the last two decades. Additionally a number of industries at various areas has been established. This abrupt increase in the population and discharge from the industries have affected the drinking water quality in the valley. To assess these affects, nine ground water samples taken from densely populated and industrial areas were analyzed for their physicochemical (taste, order, color, temperature, conductivity, turbidity, alkalinity, $\mathrm{pH}$, total hardness and total dissolved salts) and concentrations of cations ( $\mathrm{Na}, \mathrm{K}, \mathrm{Fe}, \mathrm{Mn}, \mathrm{Co}, \mathrm{Ni}, \mathrm{Cu}, \mathrm{Cd}$ and $\mathrm{Pb}$ ) by Flame Photometer and Atomic Absorption Spectrometer. The results obtained were compared with both Pakistan National Standards (PNS) for drinking water Quality (2010) and World Health Organization (WHO), standards for drinking water. All the results were in the limits of the standards except cobalt $(0.095-0.12 \mathrm{mg} / \mathrm{L})$ and cadmium $(0.0348-0.041 \mathrm{mg} / \mathrm{L})$ which were found to be in high concentrations that are attributed to the anthropogenic activates.
\end{abstract}

[DOI: 10.22401/ANJS.22.3.03]

Keywords: Elemental analysis; Physical parameters; Ground water, Spectroscopy, Quetta Valley.

\section{Introduction}

The main source for drinking water is the groundwater that contains more than $90 \%$ of fresh water is a vital source of drinking water for human beings and other living organisms [1]. Clean water vouchsafes good health of people and a key indicator for the development of a country. It has been estimated that in the next four decades [2] the urban population of the developing countries will increase by 3 billion. Due to anthropogenic activities, the average temperature of the earth is being raised which is a key factor for changing the climatic pattern to an extreme level. Consequently, the precipitation pattern is being changed while turning some regions of the world wetter while the other drier [3]. Meanwhile, besides diminishing level of groundwater in most regions of the world, it has been contaminated by natural and most apparently by anthropogenic activities, agriculture and industrialization [4]. In the present time the ubiquity of heavy elements and trace elements and the change in the physical properties of water cannot be denied.
The water contaminated with heavy metals are altogether dangerous for health [5], though the trace elements are needed in very small amount for the metabolic activities of the organisms but their high doses can be lethal [6]. According to a study; contaminated water causes 2-12 million deaths per year throughout the world [7].

Physical parameters of water mainly involve taste, color, odor, turbidity, alkalinity, hardness, total dissolved solids and conductivity. The level of theses parameters are disturbed by natural and anthropogenic activities [8,9]. Whereas, color, odor and turbidity which directly interfere with the aesthetic value of water, can also be the cause or sign of increased microbial activities in any water body [10]. Alkalinity and hardness are interdependent parameters [11]. Hardness of water is mainly caused by $\mathrm{Ca}$ and $\mathrm{Mg}$ ions. Hard water is the main cause of hair loss, lathering of the soap, cardiovascular diseases, reproductive failure and growth retardation $[12,13]$. Total dissolved salts (TDS) which is directly related to conductivity, causes a 
reduction in performance and health while in higher doses, it can be lethal [14,15].

Heavy and trace elements such as $\mathrm{Na}, \mathrm{K}$, $\mathrm{Fe}, \mathrm{Mn}, \mathrm{Se}, \mathrm{Co}, \mathrm{Ni}, \mathrm{Cu}, \mathrm{Cd}, \mathrm{Zn}$, As and $\mathrm{Pb}$ are generally present in groundwater in very small quantity; but sometimes the optimum value of these elements exceeds in drinking water. The main sources of heavy elements in groundwater may be natural or most apparently anthropogenic sources including industrial, agricultural and municipal wastes [16]. They are the main cause of kidney impairment, respiratory tract diseases, an increased rate of Osteoporosis nervous disorders, gonadal dysfunction in man, disturbed calcium metabolism, mitochondrial injury, interference in the enzyme activities, abdominal cramps, sleeplessness, irritability, headache and joint pain $[17,18]$. Trace elements are required in a minute quantity to perform metabolic activities, impulses and transport inside the cell. But their excessive amount can be lethal for human beings causing a number of toxicities such as clastogenic effects in human cells causes necrosis [19], changes in appetite level nausea [20], diarrhea, gastrointestinal disturbances, headache, shortness of breath and fatigue, carcinogenesis, mutagenesis etc $[21,22]$.

Drinking water should be free from all sorts of contamination. Due to the absence of proper monitoring and management; water contamination is rampant throughout most areas of the world especially Pakistan due to population increase, urbanization, heavy usage of agrochemicals, industrialization, natural and other anthropogenic activities. Groundwater is the only source in Quetta valley which is used for domestic and agricultural purpose. But its depletion has been taking place by leaps and bounds. Moreover, the improper drainage of huge municipal wastes from the Valley may have a greater contribution to the contamination of drinking water. The discharge of several hospitals and different industries make complex the common municipal waste.

This research study aimed to quantify the various physicochemical and elemental levels in the ground water of the Quetta valley and to compare these results with standards for the drinking water established by Pakistan and
World health organization. Through this study a water quality index for the city of Quetta could be established that will increase the awareness in the society as well as help the Government for future planning of drinking water.

\section{Experimental \\ Geography and geological survey of the area}

The Quetta valley is the capital city of Balochistan Province, Pakistan. The typical area is confined by longitude $66^{\circ} 50^{\prime}$ to $67^{\circ}$ $20^{\prime} \mathrm{E}$ and latitude $29^{\circ} 39^{\prime}$ to $30^{\circ} 26^{\prime} \mathrm{N}$ whereas altitude varies 550-3580 meter above mean sea level [23]. The valley has typical subtropical continental high land environment having average temperature in summer of $33^{\circ}$ $\mathrm{C}$ and winter of $2{ }^{\circ} \mathrm{C}$ [24]. On the basis of geography, the valley has been divided in to three major areas [25]; the mountain area consists in Murdar, Chiltan, Zarghoon and Takatu. These areas have some reserves of groundwater at higher depth. The Piedmont plain which exists between highland slopes and the main valley where the water table is at a relatively lower depth. The central valley; where the water table is comparatively shallow. 


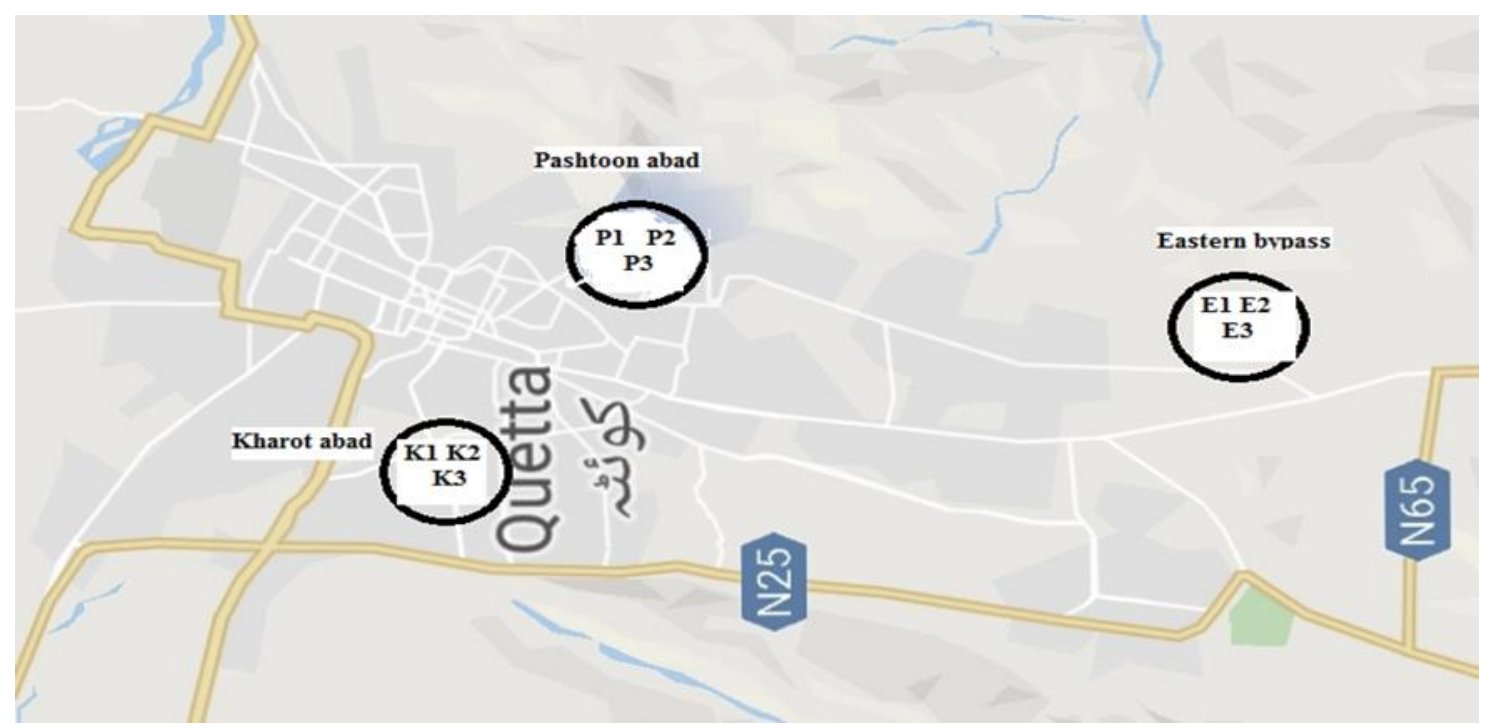

Figure: Map of the Quetta City and circles indicate the sampling areas i.e., E1, E2, E3 for Eastern Bypass, K1, K2, K3 for Kharot abad and P1, P2, P3 for Pashtoon abad. [Google Maps].

Geologically, the valley consists of several faults and folds filled with alluvial deposits. The aquifer system of the valley can be divided into four categories [25-27]. The alluvial fan consists of gravel, pebble and sand. It includes all slopes of the valley which has high hydraulic conductivity and has a good aquifer system. The alluvium which consists of clay, silt and sand. It includes the stream channels and flood plains which have intermediate hydraulic conductivity. Bostan which consist of clay, silt and sand. It includes streambed and flood plains which has low hydraulic conductivity. The Chiltan and murder range which are entirely made of limestone which has high hydraulic conductivity; thus, making it a good aquifer system. The valley has two drainage systems i.e. Northern basin and Southern basin. The Northern basin which is the main source of drinking water for Quetta city consists of Sariab Lora and Baleli river system. Whereas, the Southern basin which obtains water by flood from the mountains of Dagari and Kumbelan.

\section{Sampling}

Sample collection was done during October-November (2018) from nine sites (tube well/bores) i.e.; three are in Pashtoon abad (P1, P2, P3), three in Kharot abad (K1, $\mathrm{K} 2, \mathrm{~K} 3$ ) and three in industrial zone, Eastern bypass (E1, E2, E3) at Quetta city (as shown in figure). The method of sampling was similar to that listed $[27,28]$ by the American Public Health Association (APHA). The pre-cleaned plastic containers were used for samples collection. In order to ensure purity, the sampling bottles were flushed with plenty of the sampled water several times at a sampling site. Each sample container was labeled, taken to the lab with great care to avoid contamination, filtered through Whatman filter paper No. 4 and refrigerated at $4{ }^{\circ} \mathrm{C}$ in dark.

\section{Materials and methods}

All the glassware used during the study were per-cleaned with $20 \% \mathrm{HCL}$ for $24 \mathrm{~h}$, rinsed thoroughly with ultra-high purity (UHP) deionized water (Elga, Purelab Option UK) and stored in plastic-zip bags before use to prevent contamination. All the reagents and salts used for the study were of analytical grade (BDH, Merck) unless not stated, solution and stocks were made in UHP deionized water from these salts and commercially available Atomic Absorption standards (1000 ppm) for metals were used. All of these solutions were diluted with UHP water before use.

\section{Instrumentation and Procedure}

The physical and chemical parameters of the collected water samples were analyzed by the methods of the American Public Health Association (APHA) for water analysis [29]. 
At the moment when samples were being collected, the physical parameters such as conductivity, $\mathrm{pH}$ and temperature of all water samples were determined by conductivity meter (HI-8033, HANNA Instruments, UK), $\mathrm{pH}$ meter (Model-3305, Jenway, UK) and thermometer respectively, while the other physical parameters were determined in the laboratory. Total alkalinity was determined by electrometric titration [30] while Phenolphthalein and mixed indicator (Methyl Orange + Bromocresol) and the end points were noted for concordant values. TDS were determined by evaporating dish method. Each sample was filtered and evaporated at $110^{\circ} \mathrm{C}$. After evaporation, the dish was cooled and weighed [31] as final which was computed with the initial weight and the readings were noted. Determination of total hardness was carried out by complexometric EDTA titration that uses Erichrome black T (EBT) as an indicator. In order to maintain $\mathrm{pH}$ of the solution between $9-10, \mathrm{NH}_{4} \mathrm{Cl}+\mathrm{NH}_{4} \mathrm{OH}$ was used as a buffer and the readings were noted for concordant values [32]. Turbidity was determined by using turbidimeter. The standard solution was prepared by mixing $5 \mathrm{ml}$ of each hydrazine sulphate and hexamethylenetetramine (4000 NTU) which was diluted to 200 NTU. This concentration was used for the calibration of the instrument. Each sample was run through the instrument and the readings were noted.

Elemental analysis was done by using Flame Photometer (Jenway, Model PFP7, UK) and Atomic Absorption Spectrophotometer (Thermo- Electron Corporation, S4 AA System, Ser No, GE711544, China). The concentration of $\mathrm{Na}^{+1}$ and $\mathrm{K}^{+1}$ were determined with the help of Flame Photometer after calibrating with standards. The quantity of $\mathrm{Cu}^{+2}, \mathrm{Co}^{+2}, \mathrm{Fe}^{+2}, \mathrm{Mn}^{+2}, \mathrm{Ni}^{+2}, \mathrm{Cd}^{+2}$ and $\mathrm{Pb}^{+2}$ were determined by Atomic Absorption Spectrometer after obtaining a calibration curve with five standards for each element. The AAS instrument was allowed for 30 minute to stabilize before use.

\section{Results and Discussion}

The results of various physicochemical properties and levels of different cations of water samples acquired are given in Tables (1 and 2). All the results obtained are compared with Provisional Guidelines of Drinking Water, World Health Organization [19] and Pakistan National Standards [33] for drinking Water Quality-2010. The levels of these parameters in ground water depend upon many factors including the depth of water table (more distance decreases the chance of contamination by reacting with soil/filtration) and the quantity of precipitation (less rainfall will result in less contaminants entering the ground water during recharge) [34]. The water table of Quetta valley is more than $300 \mathrm{~m}$ and soon the city will face a water crisis in the near future [35].

\section{Physical Parameters}

Different physical parameters of the water samples were analyzed and the results are shown in Table (1). The taste, order and color of all the water samples were not detected. The results obtained for temperature (noted at the time of sampling that ranges from 21 to $23^{\circ} \mathrm{C}$ ), conductivity ( 0.4 to $0.82 \mu \mathrm{S} / \mathrm{cm})$, turbidity $(0.6$ to $1.3 \mathrm{NTU}$ ), alkalinity caused by $\mathrm{CO}_{3}^{-2}$, $\mathrm{HCO}_{3}{ }^{-1}$ and $\mathrm{OH}^{-1}$ [10] (133 to $\left.186 \mathrm{mg} / \mathrm{L}\right), \mathrm{pH}$ (7.1 to 7.9 ), total hardness ( 55 to $73 \mathrm{mg} / \mathrm{L}$ ) and total dissolved salts is mainly due to sulfates, chlorides, carbonates and bicarbonates (143.4 to $262.6 \mathrm{mg} / \mathrm{L}$ ). All of these results are within the limits of PNS and WHO standards values. 
Table (1)

Result obtained for physicochemical parameters of water samples.

\begin{tabular}{|c|c|c|c|c|c|c|c|c|c|c|c|}
\hline \multirow{3}{*}{ Parameters } & \multirow{2}{*}{\multicolumn{3}{|c|}{$\begin{array}{c}\text { Sample ID } \\
\text { Pashtoon abad } \\
\end{array}$}} & \multirow{2}{*}{\multicolumn{3}{|c|}{$\begin{array}{c}\text { Sample ID } \\
\text { Kharot abad } \\
\end{array}$}} & \multicolumn{3}{|c|}{ Sample ID } & \multirow{3}{*}{ *PNS } & \multirow{3}{*}{$\dagger \mathrm{WHO}$} \\
\hline & & & & & & & $\mathbf{E a}$ & ern by & & & \\
\hline & P1 & P2 & P3 & K1 & K2 & K3 & E1 & E2 & E3 & & \\
\hline Taste & ***ND & $\mathrm{ND}$ & ND & ND & ND & ND & ND & $\mathrm{ND}$ & ND & None & None \\
\hline Odor & ND & ND & ND & ND & ND & ND & ND & $\mathrm{ND}$ & ND & None & None \\
\hline Color & ND & $\mathrm{ND}$ & ND & ND & ND & ND & ND & $\mathrm{ND}$ & ND & $\leq 15$ TCU & $\leq 15 \mathrm{TCU}$ \\
\hline Temperature $\left({ }^{\circ} \mathrm{C}\right)$ & 22 & 22 & 23 & 22 & 23 & 23 & 22 & 21 & 23 & ****NA & NA \\
\hline Conductivity $(\mu \mathrm{S} / \mathrm{cm})$ & 0.50 & 0.48 & 0.40 & 0.53 & 0.82 & 0.74 & 0.60 & 0.53 & 0.51 & NA & 250 \\
\hline Turbidity (NTU) & 0.8 & 0.8 & 0.9 & 1.1 & 0.9 & 1.3 & 0.8 & 0.6 & 0.9 & $<5$ & $<5$ \\
\hline Alkalinity (mg/L) & 171 & 162 & 176 & 133 & 143 & 137 & 175 & 172 & 186 & NA & $\begin{array}{ll}<200 \\
\end{array}$ \\
\hline pH & 7.3 & 7.1 & 7.3 & 7.3 & 7.4 & 7.4 & 7.8 & 7.8 & 7.9 & $6.5-8.5$ & $6.5-8.5$ \\
\hline Total hardness $(\mathrm{mg} / \mathrm{L})$ & 55 & 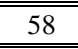 & 57 & 61 & 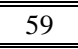 & 62 & 71 & 73 & 71 & $\angle 500$ & $\begin{array}{ll}200 \\
\end{array}$ \\
\hline TDS (mg/L) & 224.6 & 233.6 & 250.6 & 168.8 & 173.6 & 143.4 & 248.2 & 262.6 & 248.8 & $<1000$ & $<1000$ \\
\hline
\end{tabular}

$\uparrow$ World Health Organization, standards for drinking water.

* Pakistan National Standards for drinking water Quality (2010)

** Not detected

*** Not available

\section{Chemical Parameters}

Chemical parameters were analyzed and the results are given in Table (2), which show that, sodium, potassium, iron and manganese are in the range of both WHO and PNS standards, nickel, copper and lead are below our detection limits and cobalt and cadmium are above the prescribed standards. The sources of cobalt include wind-blown dust, seawater spray, volcanoes, forest fires, and continental and marine biogenic emissions, burning of fossil fuels, sewage sludge, phosphate fertilizers, mining and smelting of cobalt ores, processing of cobalt alloys, and industries that use or process cobalt compounds etc [36] and cadmium include pigments in plastics, electric batteries, electronic components, anticorrosive, electroplated onto steel and phosphate fertilizers. The surrounding of Quetta valley is mostly agricultural area that uses different fertilizer and the number of automobiles is also increasing day by day which uses fossil fuel and storage batteries. The storage batteries are not only used by automobiles, but homes are diverting from main power supplies to the solar energy systems which use storage batteries. So the elevated concentrations of cobalt and cadmium could be attributed to these anthropogenic activities. 
Table (2)

Result of chemical parameters of water samples.

\begin{tabular}{|c|c|c|c|c|c|c|c|c|c|c|c|}
\hline \multirow{3}{*}{ Parameters } & \multirow{2}{*}{\multicolumn{3}{|c|}{$\begin{array}{c}\text { Sample ID } \\
\text { Pashtoon abad } \\
\end{array}$}} & \multirow{2}{*}{\multicolumn{3}{|c|}{$\begin{array}{c}\text { Sample ID } \\
\text { Kharot abad } \\
\end{array}$}} & \multicolumn{3}{|c|}{ Sample ID } & \multirow{3}{*}{ *PNS } & \multirow{3}{*}{$\dagger \mathrm{WHO}$} \\
\hline & & & & & & & \multicolumn{3}{|c|}{ Eastern bypass } & & \\
\hline & P1 & $\mathbf{P 2}$ & P3 & K1 & $\mathrm{K} 2$ & K3 & E1 & E2 & E3 & & \\
\hline $\mathbf{N a}(\mathrm{mg} / \mathrm{L})$ & 8.2 & 8.3 & 7.9 & 10.1 & 7.9 & 9.2 & 10.2 & 9.8 & 8.8 & $\mathrm{NA}$ & 200 \\
\hline $\mathbf{K}(\mathrm{mg} / \mathrm{L})$ & 1.2 & 1.2 & 1.0 & 1.4 & 1.4 & 1.3 & 1.2 & 0.9 & 1.3 & NA & $<50$ \\
\hline Fe $(\mathrm{mg} / \mathrm{L})$ & 0.2469 & 0.0597 & 0.0669 & 0.1051 & 0.1326 & 0.1493 & 0.099 & 0.0841 & 0.0899 & $\mathrm{NA}$ & $0.5-50$ \\
\hline Mn (mg/L) & 0.0672 & 0.1105 & 0.0843 & 0.1041 & 0.1138 & 0.1313 & 0.097 & 0.0873 & 0.1009 & $\leq 0.5$ & $\leq 0.5$ \\
\hline Co (mg/L) & 0.102 & 0.106 & 0.112 & 0.120 & 0.119 & 0.095 & 0.110 & 0.099 & 0.095 & NA & $\begin{array}{c}0.001- \\
0.01\end{array}$ \\
\hline $\mathbf{N i}(\mathrm{mg} / \mathrm{L})$ & $* * \mathrm{BDL}$ & BDL & BDL & BDL & $\mathrm{BDL}$ & $\mathrm{BDL}$ & BDL & BDL & BDL & $\leq 0.02$ & 0.02 \\
\hline $\mathbf{C u}(\mathrm{mg} / \mathrm{L})$ & $\mathrm{BDL}$ & $\mathrm{BDL}$ & $\mathrm{BDL}$ & BDL & $\mathrm{BDL}$ & $\mathrm{BDL}$ & $\mathrm{BDL}$ & $\mathrm{BDL}$ & BDL & 2 & 2 \\
\hline Cd (mg/L) & 0.0407 & 0.0345 & 0.0363 & 0.0348 & 0.0363 & 0.0349 & 0.038 & 0.0364 & 0.0338 & 0.01 & 0.003 \\
\hline $\mathbf{P b}(\mathrm{mg} / \mathrm{L})$ & $\mathrm{BDL}$ & $\mathrm{BDL}$ & $\mathrm{BDL}$ & $\mathrm{BDL}$ & $\mathrm{BDL}$ & $\mathrm{BDL}$ & $\mathrm{BDL}$ & $\mathrm{BDL}$ & BDL & $\leq 0.05$ & 0.01 \\
\hline
\end{tabular}

$\dagger$ World Health Organization, standards for drinking water.

* Pakistan National Standards for drinking water Quality (2010).

** Below Detection Limit.

$* * *$ Not available.

\section{Conclusion}

Both the physical and chemical contamination makes water hazardous to health and aesthetically bad for consumers. Though groundwater is not highly vulnerable to the sources of contamination but sometimes the natural and anthropogenic activities are directly and indirectly involved in its contamination. In the present study, three different thickly populated areas of Quetta valley were selected for their physicochemical and elemental analysis to evaluate the effects of population on it. Most of the physical and chemical parameters analyzed were compared with both Pakistan National Standards for drinking water Quality (2010) and World Health Organization standards for drinking water. These results were found to be within the limits of both standards except cobalt and cadmium which were present in elevated levels. The reasons for their high levels are mostly anthropogenic activities such as the use of phosphate fertilizers and storage batteries by automobiles and in houses.

\section{Acknowledgement}

The authors are thankful to the Department of Chemistry, University of Balochistan for providing assistance and Lab facilities.

\section{References}

[1] Kanmani S \& Gandhimathi R. "Investigation of physicochemical characteristics and heavy metal distribution profile in groundwater system around the open dump site". Applied Water Science, 3(2): 387-99, 2013.

[2] McDonald RI, Green P, Balk D, Fekete BM, Revenga C, Todd M and Montgomery M. "Urban growth, climate change, and freshwater availability". Proceedings of the National Academy of Sciences, 108(15): 6312-7, 2011.

[3] Marmot M, "Commission on Social Determinants of Health. Achieving health equity: from root causes to fair outcomes". The Lancet, 370(9593): 1153-63, 2007.

[4] Salam HE \& Salwan AA. "Water Quality Assessment of Al-Gharraf River, South of Iraq Using Multivariate Statistical Techniques" Al-Nahrain J. of Science, 20(2), 114-122, 2017

[5] Martin S \& Griswold W. "Human health effects of heavy metals". Environmental Science and Technology briefs for citizens, 15:1-6, 2009.

[6] Prashanth L, Kattapagari KK, Chitturi RT, Baddam VR and Prasad LK. "A review on role of essential trace elements in health and 
disease". Journal of Dr. NTR University of health sciences, 4(2): 75-82. 2015.

[7] Gleick PH. Dirty-water: estimated deaths from water-related diseases 2000-2020. Oakland: Pacific Institute for studies in Development, environment, and security; 2002.

[8] Mazor, Emanuel. "Applied chemical and isotopic groundwater hydrology". (1990).

[9] Patil PN, Sawant DV and Deshmukh RN. "Physico-chemical parameters for testing of water-A review". International Journal of Environmental Sciences, 3(3):1194, 2012.

[10] Scatena FN. Drinking water quality. Drinking Water from Forests, Chapter 2, 2000 http://infohouse.p2ric.org/ref/16/15665.pdf

[11] Srinivasan G, Srinivas CR, Mathew AC and Duraiswami D." Effects of hard water on hair". International journal of trichology, 5(3):137, 2013.

[12] Borghetty HC \& Bergman CA. "Synthetic detergents in the soap industry". Journal of the American Oil Chemists' Society, 27(3): 88-90, 1950.

[13] Sengupta P. "Potential health impacts of hard water". International journal of preventive medicine, 4(8): 866, 2013.

[14] Wood WW. Guidelines for collection and field analysis of ground-water samples for selected unstable constituents. US Government Printing Office; 1976.

[15] Patterson HH, Johnson PS, Epperson WB and Haigh RD. "Effect of total dissolved solids and sulfates in drinking water for growing steers", South Dakota State University Beef Report. Beef, 15:101-104, 2003.

[16] Sörme L \& Lagerkvist R. "Sources of heavy metals in urban wastewater in Stockholm". Science of the Total Environment, 298(1-3):131-45, 2002.

[17] Kazantzis G. "Renal tubular dysfunction and abnormalities of calcium metabolism in cadmium workers". Environmental health perspectives, 28: 155-9, 1979.

[18] WHO G. "Guidelines for drinking-water quality. World Health Organization", 216: 303-4, 2011.

[19] Hamilton-Koch W, Snyder RD and Lavelle JM. "Mental-induced DNA damage and repair in human diploid fibroblasts and
Chinese hamster ovary cells". Chemicobiological interactions, 59: 17-28, 1986.

[20] Underwood ET \& Mertz W, Introduction. In Truce Elements in Human and Animal Nutrition, vol. 1, pp. 1-20, San Diego, CA, 1987.

[21] Sunderman Jr FW, Dingle B, Hopfer SM and Swift T. "Acute nickel toxicity in electroplating workers who accidently ingested a solution of nickel sulfate and nickel chloride". American journal of industrial medicine, 14(3): 257-66, 1988.

[22] Araya M, McGoldrick MC, Klevay LM, Strain JJ, Robson P, Nielsen F, Olivares M, Pizarro F, Johnson L and Poirier KA. "Determination of an acute no-observedadverse-effect level (NOAEL) for copper in water". Regulatory Toxicology and Pharmacology, 34(2): 137-45, 2001.

[23] Alam K. Evaluation of aquifer system in Quetta valley through geographical methods and groundwater flow modeling (Doctoral dissertation, University of Punjab, Lahore-Pakistan), 2010.

[24] Kakar N, Kakar DM, Khan AS, Khan SD. "Land Subsidence Caused by Groundwater Exploitation in Quetta Valley, Pakistan". International Journal of Economic and Environmental Geology, 10: 10-9. 2019.

[25] Kazmi AH, Abbas $G$ and Younas S. "Water resources and hydrogeology of Quetta Basin, Balochistan, Pakistan". Geological Survey of Pakistan, Quetta. 2005.

[26] Kazmi AH \& Reza SQ. "Water supply of Quetta Basin, Balochistan, Pakistan”. Geol. Surv. Pakistan Rec., 20(2): 97-138, 1970.

[27] Kazmi SA. Geohydrology of Quetta Valley. Hydrogeology Directorate, Reclamation Division, Water and Power Development Authority, Pakistan, 1973.

[28] American Public Health Association and others; Standard methods for the examination of water and wastewater, 12th ed; 1965.

[29] USEPA, "Superfund Program Representative Sampling Guidance": Vol. 3, 1997.

[30] Barnes I. "Field measurement of alkalinity and pH". USGPO, 1964.

[31] Howard CS. "Determination of total dissolved solids in water analysis". 
Industrial \& Engineering Chemistry Analytical Edition, 5(1): 4-6, 1933.

[32] Goetz CA, Loomis TC and Diehl H. "Total Hardness in Water. Stability of Standard Disodium Dihydrogan Ethylenediamine Tetraacetate Solutions". Analytical Chemistry, 22(6): 798-9, 1950.

[33] Khwaja, MA \& Anum A. "Comparative Assessment of Pakistan National Drinking Water Quality Standards with Selected Asian Countries and World Health Organization”. 2018.

[34] A Dictionary of Earth Sciences. Encyclopedia.com. 26 May. 2019 $<$ https://www.encyclopedia.com>

[35] Khan, Feisal. "Water, governance, and corruption in Pakistan". RUNNING ON EMPTY, 2010 (2009): 2025, 2003.

[36] Barceloux DG \& Barceloux D. "Cobalt. Journal of Toxicology": Clinical Toxicology. 37(2): 201-16, 1999. 